\title{
Abbreviations of key sources
}

\section{EPICURUS}

I have used the following: Epicurus (1994) The Epicurus Reader, translated and edited by B. Inwood and L.P. Gerson, Indianapolis, IN: Hackett Publishing Company. I have followed the practice Inwood and Gerson use in the index, citing the text number (here, in roman numerals) and then the reference numbers within each text. For instance, the famous saying 'death is nothing to us' is in text 4 , reference number 124 . This is rendered as:

Epic IV.124.

\section{LUCRETIUS}

There are many verse and prose translations of De Rerum Natura. I have opted for one of the most celebrated of the latter: Lucretius (2001) On the Nature of Things, translated by Martin Ferguson Smith, revised edition, Indianapolis, IN: Hackett Publishing. This is referenced in the following as DRN followed by the relevant book (in roman numerals) and line references, for instance:

DRN IV.534-89.

\section{ARISTOTLE}

I have relied entirely upon the Nicomachean Ethics. I am aware that some regard the Eudemian Ethics to be as significant a source for Aristotle's ethics but, unconvinced, I decided to neglect it. The edition I relied upon was Aristotle (1999) Nicomachean Ethics, translated by Terence Irwin, 2nd edition, Indianapolis, IN: Hackett Publishing. Actually, there might be little point in telling you that, since I ended up not actually quoting him and relying upon notes in the alternative translation by Rowe and Broadie (2002)! In any event, the Nicomachean Ethics has been abbreviated to $N E$ and I have used the standard marginal line numbering (originating with Immanuel Bekker's 1831 edition). Hence the very first line of the Nicomachean Ethics would be rendered in a citation as:

NE 1094al. 
I also make mention in Chapter 6 of De Anima, Politics, Metaphysics and Physics. However, for these publications I have just used the standard Harvard system with page references from the relevant editions (see the References section). 
Tony Fitzpatrick - 9781786432018

Downloaded from PubFactory at 04/26/2023 05:37:45AM via free access 